\title{
COMPARATIVE ANALYSIS OF BIO-BUSINESS MODELS AND JUSTIFICATION OF THEIR MANAGEMENT IMPROVEMENT
}

\begin{abstract}
Judita ASTROVIENÉ, Department of Business and Rural Development Management, Faculty of Bioeconomy Development, Vytautas Magnus University, K. Donelaičio g. 58, LT-44248 Kaunas, Lithuania, judita.astroviene@ vdu.lt (corresponding author) Jolita GREBLIKAITE், Department of Business and Rural Development Management, Faculty of Bioeconomy Development, Vytautas Magnus University, K. Donelaičio g. 58, LT-44248 Kaunas, Lithuania, jolita.greblikaite@vdu.It

The management models and concepts that the business applies in its activities determine the decision-making process, work of organization, and other operating principles. In businesses whose activities are complex or specific, i.e. in high value-added biobusinesses, traditional management models are not suitable in some cases - For example Forgo (2004) says that only organizations that are able to turn ideas into products and sell them in a short period of time can develop effectively. In the case of bio-business development, research may take time, but this does not necessarily mean that the company will not develop efficiently. The aim of this study is to perform a comparative analysis of bio-business models and to substantiate the need for their improvement - the management model must be adapted to the size of the company, the nature of economic activity, the external environment. Today's biotechnology industry also needs to take a more disciplined approach to management processes that go beyond traditional organizational boundaries. The research is based on the analysis, synthesis, systematization and comparison of scientific literature, statistical data and documents. The study found that while there are sufficient prospects for using bio-waste as bio-raw materials and developing bio-businesses in rural areas, existing models may be difficult to adapt from a managerial point of view and should be improved. The most obvious of the issues examined is that there is still a lack of solutions for a more fluent flow of business processes, especially for the adequate use of bio-waste, i.e. so that high added value is obtained from them. It has been found that the use of bio-raw materials for the manufacture of products would not only create high economic added value, but also would build jobs in rural areas. Because the development of a bio-business from idea to final product is a long process that can take decades, such processes require appropriate business models and their management.
\end{abstract}

Keywords: biobusines, biobusines model, high-added value.

\section{INTRODUCTION}

Relevance of the topic: Traditionally, a business model is considered to be the way in which a company creates value for its stakeholders (Shimasaki, 2014). All bio-businesses can be perceived as certain processes consisting of five stages of development: research, expansion, testing and registration, production and trade (Kiškis and Limba, 2016). The management system of the organization is also very important for effective development. An organization's management system can consist of many structural elements: a functional position or the administration of managerial tasks that require technology to manage.

Relevance of the study: bio-businesses differ from traditional businesses in that they usually have a longer product development process, which can take from a few to several years; bio-businesses are considered risky due to long product development, and such businesses may require significantly higher investments. "Bio-business requires constant funding for research and production, IP protection, patenting" (Białek-Jaworska and Gabryelczyk, 2016). Although the analyzed studies discuss bio-business models, they emphasize the importance of management in the development of bio-businesses; they lack a broader interpretation and analysis.

Methods: the research is based on the analysis, synthesis, systematization and comparison of scientific literature, statistical data and documents.

Methodology: the study analyzes bio-business models, which are categorized according to whether they are product-oriented or service-oriented. These traditional business models are compared to circular business models. Improving the management of bio-business models is based on highlighting the main management criteria that arise in the development of circular models of bio-business.

Subject of the research: bio-business models.

The aim of the research: to analyze the business models of bio-businesses and to substantiate the improvement of their management.

\section{COMPARATIVE ANALYSIS OF BIO-BUSINESS MODELS}

Copyright (C) 2021 The Authors. Published by Vytautas Magnus University. This is an open-access article distributed under the terms of the Creative Commons Attribution License (CC BY 4.0), which permits unrestricted use, distribution, and reproduction in any medium, provided the original author and source are credited. 
Bio-based companies can be grouped into open (open to innovation, using the services of other companies) and closed (research, product development, and distribution are carried out only independently, without the help of other companies). Regardless of the chosen business relationship with the external environment, all bio-businesses can be categorized according to certain models. The scientific literature distinguishes three main linear business models of biobusiness, which define business development according to life cycles (Almirall and Casadesus-Masanell, 2017; Bourguignon, 2016):

1. Vertical (product): when extremely high value-added products are developed for many years (10-20 years), often limited to the production of several products, involved in at least several stages of the product life cycle. This business model is considered one of the riskiest;

2. Horizontal: when companies conduct research and provide services. Such companies offer various patents and licenses; one life cycle consists of several stages. The added value generated by such businesses is not high;

3. Hybrid model is the joint development of the first two business models, where companies do both: develop high value-added products and provide services (e.g., manufacture biotechnology devices and license biotechnology devices manufactured by other companies).

Comparing the business models of bio-business in terms of added value creation, it can be seen that the vertical model creates the highest added value, but its riskiness is also higher than that of the horizontal model. Both models can be developed in different forms. As the vertical model creates higher added value, it is appropriate to examine it more broadly. This model can be divided into the following forms (Shimasaki, 2014; Dixon, 2011):

1. FIBCO (fully integrated biopharmaceutical company) - it is often a model of large corporations, where all product development processes and stages are carried out in the same company;

2. FIBNET (fully integrated biopharmaceutical network) - it is a model in which developing companies carry out part of the product development processes and stages independently and the other part in collaboration with other companies;

3. RIPCO (research intensive pharmaceutical companies) - it is a model in which companies carry out intensive research and sell information or primary products to other companies;

4. FIDDO (fully integrated drug discovery and development organization) - the essence of the model is the improvement of the product produced by another company at all stages;

5. NRDO (no research, development only) - a production model where no research is carried out and the production is purchased;

6. BIEM 2.0 (bioenterprise innovation expertise model) - expert model of bio-enterprise innovation, which identifies twelve categories belonging to bio-enterprise: science and technology, intellectual property, venture capital, bio-enterprise finance, bio-enterprise law, strategic market insights, regulatory expertise, strategic relations with media, bio-ethics, bio-enterprise information systems, social policy, multinational expertise (Gunn et al., 2015).

Another classification of linear bio-business models found in the scientific literature is as follows (Kiškis and Limba, 2016):

1. Product model - when for a long period of time (up to 12 years), a very small company usually carries out very high-intensity research by highly qualified employees, creating high added value, but a risky model, often operating in the international market, earning revenue from product or stock sales.

2. Service model - when for a short period of time (1-3 years), a medium-sized company usually conducts mediumintensity research; the added value is not high; a less risky model; often operating in the local or regional market, earning revenue from the sale of services.

The main differences between bio-business product and service models are the period during which they are developed (in the vertical model the development period is significantly longer) and the added value created (in the vertical development model it is significantly higher). A comparison of traditional models is presented in Table 1.

Table 1. Comparison of linear bio - business models

\begin{tabular}{|l|l|}
\hline \multicolumn{1}{|c|}{ Service model } & \multicolumn{1}{c|}{ Product model } \\
\hline $\begin{array}{l}\text { Open: } \\
-\quad \text { focused on early-stage research, } \\
-\quad \text { develops research tools for technologies }\end{array}$ & $\begin{array}{l}\text { Open: } \\
\text { developing end products for consumers and other businesses }\end{array}$ \\
$-\quad$ Models: FIBNET, FIDDO, NRDO, BIEM \\
$\quad$ Models: RIPCO & $\begin{array}{l}\text { Closed } \\
\text { developing end products for consumers } \\
\text { Models: FIBCO }\end{array}$ \\
\hline Vertical & More risky, high added value is created \\
\hline Horizontal & Less risky, creates average added value \\
\hline Hybrid & Average risk, creates average added value \\
\hline
\end{tabular}

Source: Almirall and Casadesus-Masanell (2017), Čiurinskaitė and Paleckis (2018), Bourguignon (2016)

Having discussed possible bio-business models, it can be concluded that although vertical models are more risky and their development period is longer, but their development is more promising because the added value created is significantly higher. The relationship of the chosen business model with other businesses depends on what part of the processes and stages will be carried out independently, and what will be carried out in cooperation with other companies. 
The main disadvantage of linear business models is that business models refer only to the goods or services provided by the bio-business and what processes take place in the companies, but they do not emphasize environmental impact and compatibility with sustainable development. Therefore, it is further appropriate to discuss the circular model of bio-business.

European Commission in 2015 inducted the Circular Economy Action Plan, which emphasizes that the value of products and resources in the economy should be maintained for as long as possible and that waste generation should therefore be kept to a minimum (Motte et al., 2019): Since, as discussed earlier, linear bio-business models define only the economic aspect, it is appropriate to analyze in more detail what new aspects are included in the circular economy.

The linear model is characterized by the transformation of resources into production, consumption, and waste. It lacks sustainability, higher productivity in the use of natural resources, longer product life, re-use, re-use of used product parts in production, and recycling of waste.

A sustainable and circular economy-based business model is an innovative management process that not only creates value for stakeholders but also takes environmental considerations into account (Ferasso et al., 2020). The circular economy was created as a contrast to the linear model. It is based on a "positive value cycle", i.e. re-use of end-of-cycle goods or materials in the production cycle. In an ideal circular model, products are eco-designed, produced from renewable or recycled resources or waste from other sectors, reused, repaired, improved and finally recycled (Donner et al., 2020).

Circular business models have been developed to incorporate the principles of sustainability and the goals of sustainable development. The aim of the circular model is for companies to respond to sustainability issues and solve the problem of excessive waste generation (Horvath et al., 2019).

The principle of circular models is based on the 3R principle, which consists of three steps (D'Amato et al., 2020):

1) reduction: to reduce the amount of energy (derived from fossil resources) and the amount of waste generated, to improve production processes;

2) re-use: encouraging the re-use of used products or parts of used products instead of waste;

3) recycling: recycling of generated waste (which is not suitable for re-use) into new products.

These principles should be integrated into sustainable development, which aims to find new ways to achieve maximum production or maximum value using the same or less resources and to improve production (Trapero et al., 2018).

A comparison of linear and sustainable and circular economy-based models is presented in Table 2.

Table 2. Comparison of linear and circular business models of bio-businesses

\begin{tabular}{|l|l|l|}
\hline & \multicolumn{1}{|c|}{ Linear } & Sustainable and circular economy based models \\
\hline Regard for economic aspects & Yes & Yes \\
\hline Regard for social aspects & No & Yes \\
\hline Regard for ecological aspects & No & Yes \\
\hline Amount of waste generated & Large & Small or none at all \\
\hline Riskiness & Large & Large \\
\hline Costs & Can be high & Strives to reduce costs \\
\hline Advantages & $\begin{array}{l}\text { There are no advantages over sustainable } \\
\text { models }\end{array}$ & $\begin{array}{l}\text { Additional added value, meets the goals of } \\
\text { sustainable development, innovative activities }\end{array}$ \\
\hline Disadvantages & $\begin{array}{l}\text { Incompatible with the objectives of } \\
\text { sustainable development }\end{array}$ & $\begin{array}{l}\text { Requires specific knowledge and managerial } \\
\text { skills }\end{array}$ \\
\hline
\end{tabular}

Source: Trapero et al. (2018), Reim et al. (2019), D'Amato et al. (2020)

Linear business models are incompatible with the goals of sustainable development, which is why companies must integrate the principles of sustainability and the circular economy when developing bio-businesses. A sustainable and circular economy-based business model is an innovative management process that not only creates value for stakeholders but also involves environmental considerations. The circular economy was created as a contrast to the linear model. It is based on a "positive value cycle", i.e. y. re-use of end-of-cycle goods or materials in the production cycle (Donner et al., 2020).

To sum up, social and environmental considerations are at the heart of sustainable and circular business models. Great emphasis is placed on avoiding waste in general and turning it into high-quality secondary resources, which will require a well-functioning market for secondary raw materials.

The development of high value-added bio-businesses in rural areas is specific in that workers in rural areas often have little understanding of the market, no links with external partners, lack funding for raw materials, substances, investment in equipment, infrastructure, etc., especially in the first years of operation (Wren, 2012). Every business is unique, making it difficult to choose a universal management model. As a result, the management model must be adapted to the size of the company, the nature of economic activity, and the external environment. Today's biotechnology industry also needs to take a more disciplined approach to management processes that transcend traditional organizational boundaries (Terziovski and Morgan, 2006).

\section{JUSTIFICATION FOR IMPROVING THE MANAGEMENT OF BIO-BUSINESS MODELS}

The development of biotechnology innovations needs to be managed from idea generation to commercialization, and traditional management methods need to be replaced by new collaborative methods that foster knowledge to transcend organizational boundaries and share information with organizational partners (Gerasimov and Gerasimov, 2015). The emergence of new biotechnologies and the abundance of scientific knowledge pose new challenges for bio-business 
managers. They need to acquire new knowledge and skills, understand how to manage businesses that do not go to traditional management processes (Terziovski and Morgan, 2006).

The "SHERPA Position Paper" (Chartier et al., 2021) states that rural areas by 2040 should accelerate the development of the bioeconomy, respect circularity, sustainability, minimize the development of businesses that search for, extract, process, use, refine or sell coal and oil.

Consumers of organic products around the world are demanding ever better-quality products, and this is becoming one of the major challenges for organic businesses. Achieving quality and adapting to market needs requires a development strategy based on innovation, quality, added value (Alexieva-Nikolova and Valeva, 2021).

The bio-industry is based on the continuous transformation of scientific progress into promising commercial technologies, services or products. The biotechnology industry can therefore be understood as 'science businesses' that are very different from traditional ones in terms of the need for higher education. The development of such businesses must not have a life-threatening effect, resulting in extremely strict documentation of technologies, goods and services. Science, the product life cycle also requires the management of an extraordinarily diverse, often complex, process (Gunn et al., 2013).

An analysis of the management of bio-business models revealed that some of the major management models in the scientific literature are American and Japanese. The first is based on the management style, when led by one person to whom the employees must obey, the business feels strict discipline, formal relationships. Only the manager is responsible for the decisions and their implementation. Decisions are focused on ensuring profitability and are often made quickly. Success factors are understood as: the ability to rationally organize activities, increasing productivity, efficient use of resources, innovation. Business is dominated by a formal management and control structure (Hoffmann and Keča, 2017). The second model is more focused on the long-term goals, decisions are made in groups of employees (Hribar et al., 2018). The third model is based on the recognition of cultural differences between countries, corporate social responsibility, people-orientation and internal negotiations within the company, long-term thinking. Depending on the direction of the bio-business, all models can be practiced. Existing business and management models for managing business development focus most on business processes, but pay too little attention to functional elements, lacking management capabilities for long and complex processes.

The management system of the organization is also very important for effective development. An organization's management system can consist of many structural elements: a functional position or the administration of managerial tasks that require technology to manage. The operation and survival of a business in the market depends on optimization, the creation and development of operating mechanisms in a competitive business environment. There are very different concepts of organizational development in the scientific literature: from gradual improvement to radical changes in management systems or their components (Vilmantas and Melnikas, 2014).

According to the three directions of sustainable development, management models are subject to certain requirements (United Nations, 2015; Chartier et al., 2021): ensuring profitability, rational organization of activities, increasing work productivity, knowledge management, high product quality and added value, ring-fencing, sustainability.

It can be assumed that the business model management system should help to: develop innovative proposals that would help the organization to achieve high product quality; to introduce innovative technologies to produce new products that meet consumer needs to create flexibility in the face of changing current situations. The management system must provide a way to implement the concept and strategy for the continuous development of the organization.

The main objectives of the management system implementation are: development of new products, implementation of measures to improve the quality of products or services, increasing the efficiency of management and innovation activities, ensuring the rationality of the functional structure, improving information and software support, implementation of appropriate organizational policies. (Alexieva-Nikolova and Valeva, 2021) The organizational policy of a bio company determines the ideas, goals, strategy and culture of the management, which can be expressed in the rules of management of written or unwritten activities (Amon and Tabani, 2014). Properly formulated organizational policies anticipate operational actions that affect the development of a business. It is also appropriate to set up bio-business centers to provide information and advice on modern production methods, EU support calls, cooperation programs, crossborder projects, etc. (Alexieva-Nikolova and Valeva, 2021).

It is important to make good use of local resources, for example in regions where medicinal herbs are abundant, to turn them into high value-added medicinal products; to grow insects from which animal fats can be obtained in regions rich in food waste; in regions where cannabis is abundant for use in the production of building materials (Opening ... procurement, 2015). Such proper use of local resources ensures sustainability and creates an opportunity to offer new products to consumers. Thus, high value-added bio-businesses should offer new services and goods to modern society.

It can be concluded that the main criteria for bio-business management are the following:

1. Ensuring profitability

2. Rational organization of activities and resources

3. Increasing work productivity

4. Knowledge management

5. High product quality and added value

6. Circularity

7. Sustainability

8. Development of new products

9. Appropriate organizational policy

10. Use of existing resources (bio-waste integration). 
The requirements must be implemented through three directions of sustainable development - economic, social and environmental (Figure 1) (United Nations, 2015).

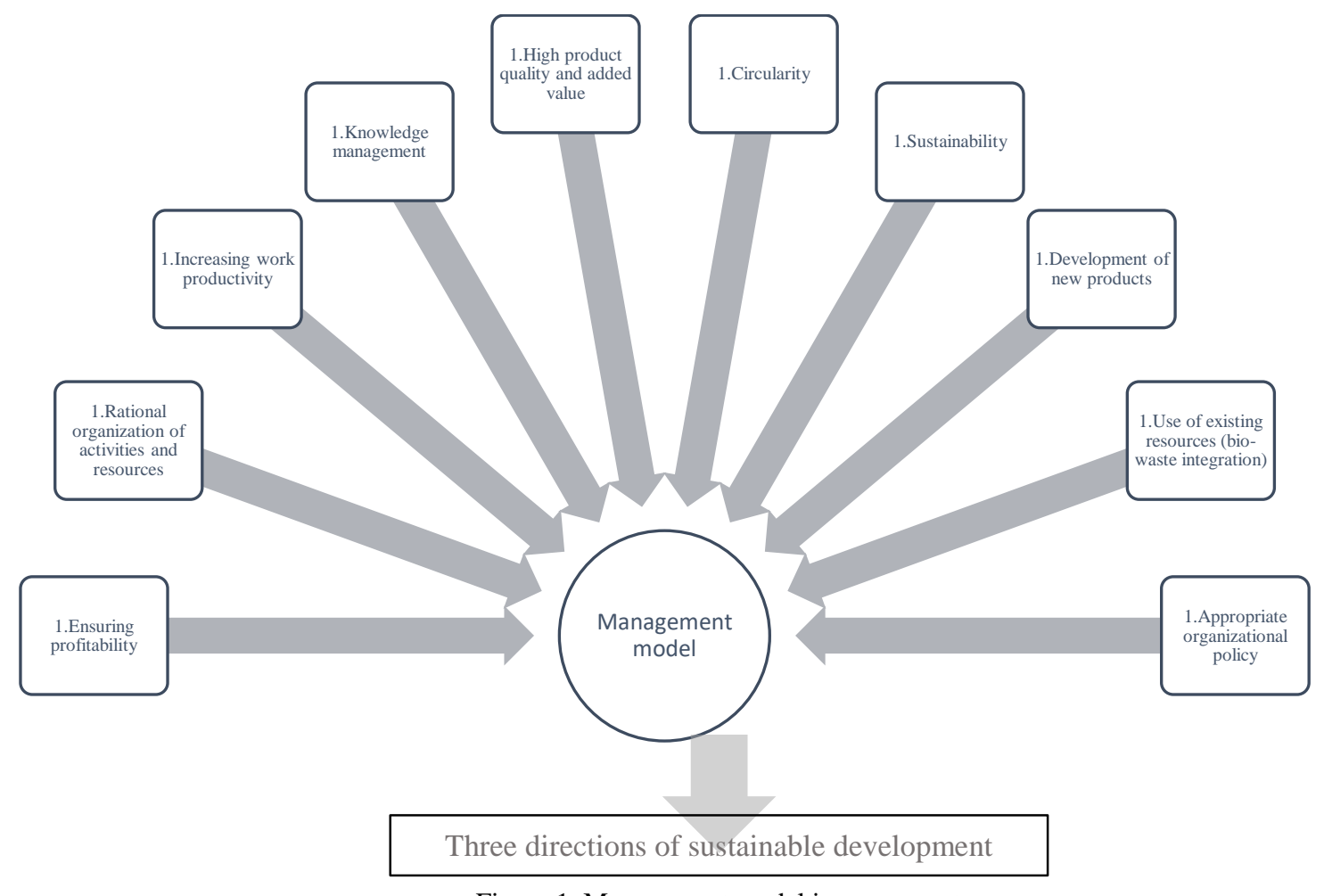

Figure 1. Management model improvement

It can be concluded that the management of the APV business model needs to cover very broad criteria, and there is currently no bio-business development model that covers such a wide list of functions and is applicable to both livestock and crop bio-businesses.

\section{CONCLUSIONS AND DISCUSSION}

In anticipation of the long-term success of bio-business development, investing in innovation and improving production processes is crucial. It is important to - create opportunities for clear innovation strategies or management practices. In this way, it is possible to ensure the innovative development of bio-businesses, the generation of new ideas, and the attraction of external partners for the creation of innovations. The emergence of new biotechnologies and the abundance of scientific knowledge pose new challenges for bio-businesses, they need to acquire new knowledge and skills, understand how to manage businesses that are not able to adapt to traditional management processes. Attention is drawn to the need to properly develop the development and production of high value-added products in order to successfully commercialize bio-businesses.

The difficulty in applying existing business models and their management theories to bio-business organizations is that theories state that only those organizations that are able to turn ideas into products and sell them in a short period of time can develop effectively. In the case of bio-business development, research may take time, but this does not necessarily mean that the company will develop inefficiently. The high value-added business development model must include more new functions and processes that may arise from the development of high value-added products, especially when it comes to business model selection, knowledge, technology management or integration of bio-waste into biobased or product production processes, linear model transformation to the rings.

The following criteria are set for the management model: it should ensure profit, rationally organize activities and resources; labor productivity must grow; the products produced must be of high quality and value; the model should be circular; developing new products, exploiting existing resources; developing sustainably through the social, economic and ecological dimensions.

\section{REFERENCES}

1. Alexieva-Nikolova, V., Valeva, K. 2021. Anti-crisis policy of bio-enterprises in conditions of COVID 19 through innovation. International Scientific Journal Innovations, Issue 1, pp. 15-18. Available at https://stumejournals.com/journals/innovations/ 2021/1/pdf

2. Almirall, E., Casadesus-Masanell, R. 2017. Open versus Closed Innovation: A Model of Discovery and Divergence Academy of Management. Academy of Management Review, Vol. 35, No. 1. https://doi.org/10.5465/amr.35.1.zok27 
3. Amon, S., Tabani, N. 2014. The entrepreneurial marketing management and commercialization arrangements of born-global bioenterprises: the case of UK companies. Journal of Small Business \& Entrepreneurship, Vol. 27, Issue 2, pp. 143-170. https://doi.org/10.1080/08276331.2014.994696

4. Białek-Jaworska, A., Gabryelczyk, R. 2016. Biotech spin-off business models for the internationalization strategy. Baltic Journal of Management, Vol. 11(4). https://doi.org/10.1108/BJM-11-2015-0223

5. Bourguignon, D. 2016. Closing the loop. New circular economy package. Briefing. Available at http://www.europarl.europa.eu/RegData/etudes/BRIE/2016/573899/EPRS_BRI(2016)573899_EN.pdf

6. Chartier, O., Salle, E., Irvine, K., Kull, M., Miller, D., Nieto, E., Vestergård, L.O., Potters, J. Slätmo, E., Zomer, B., Iadecola, F. 2021. SHERPA Position Paper. Long-term vision for rural areas. Contribution from SHERPA. Available at https://ruralinterfaces.eu/wp-content/uploads/2021/02/SHERPA_PositionPaper-LTVRA.pdf

7. Čiurinskaitė, M., Paleckis, K. 2018. Verslo modeliai biotechnologijų įmonėse: ịvairovè ir tendencijos. Verslas XXI amžiuje. Available at http://jmk.vvf.vgtu.lt/index.php/Verslas/2018/paper/viewFile/226/119 (In Lithuanian)

8. D'Amato, D., Veijonaho, S., Toppinen, A. 2020. Towards sustainability? Forest-based circular bioeconomy business models in Finnish SME. Forest Policy and Economics, Vol. 110, 101848. https://doi.org/10.1016/j.forpol.2018.12.004

9. Dixon, J. 2011. RIPCO, FIPCO, NRDO, FIPNET, VIPCO. Nature Biotechnology. Available at http://blogs.nature.com/ tradesecrets/2011/05/31/ripco-fipco-nrdo-fipnet-vipco

10. Donner, M., Gohier, R., de Vries, H. 2020. A new circular business model typology for creating value from agro-waste. Science of The Total Environment, Vol. 716. https://doi.org/10.1016/j.scitotenv.2020.137065

11. Ferasso, M., Beliaeva, T., Kraus, S., Clauss, T., Ribeiro-Soriano, D. 2020. Circular economy business models: The state of research and avenues ahead. Business Strategy and the Environment, Vol. 29(8), pp. 3006-3024. https://doi.org/10.1002/bse.2554

12. Forgo, F. 2004. John von Neumann's Contribution to Modern Game Theory. Acta Oeconomica, Vol. 54(1), pp.73-84. https://doi.org/10.1556/aoecon.54.2004.1.5

13. Gunn, M. A., Koeplin, J. P., Lorton, P. V., Whitty, M. D. 2015. The Ignatian Pedagogy Paradigm and the Global. Jesuit Higher Education, Vol. 4(1), pp. 72-82. Available at https://epublications.regis.edu/cgi/viewcontent.cgi?article=1080\&context=jhe

14. Hoffmann, C., Keča, L. 2017. New sustainable business models in forest bio-economy to gain value added (VA) for rural areas. IUFRO 125th Anniversary Congress 2017. Available at https://bia.unibz.it/discovery/delivery?vid=39UBZ_INST: ResearchRepository\&repId=12235195590001241\#13235227640001241

15. Horvath, B., Khazami, N., Ymeri, P., Fogarassy, C. 2019. Investigating the current business model innovation trends in the biotechnology industry. Journal of Business Economics and Management, Vol. 20, Issue 1, pp. 63-85. https://doi.org/10.3846/jbem.2019.6880

16. Hribar, M., Š., Istenič, S., P., Kozina, J., ir kt. (2018). The Good Practices Catalogue of Participatory Urban Agriculture. Urban agriculture for changing cities: governance models for better institutional capacities and social inclusion (AgriGo4Cities). Available at https://www.researchgate.net/publication/331745267_The_Good_Practices_Catalogue_of_Participatory_Urban_Agriculture

17. Kiškis, M., Limba, T. 2016. Biotevhnologojų MVİ intelektinès nuosavybès strategijos. Monografija. Vilnius. (In Lithuanian)

18. Motte, M., Lillemets, J., Varnik, R. 2019. A systematic approach to exploring the role of primary sector in the development of Estonian bioeconomy. Agronomy Research, Vol. 17(1).

19. Reim, V., Parida, V., Sjodin, D., R. 2019. Circular Business Models for the Bio-Economy: A Review and New Directions for Future Research. Sustainability, Vol. 11(9). https://doi.org/10.3390/su11092558

20. Shimasaki, C. 2014. Understanding Biotechnology Business Models and Managing Risk, Biotechnology Entrepreneurship: Starting, Managing, and Leading Biotech Companies. Elsevier. https://doi.org/10.1016/B978-0-12-404730-3.00012-9

21. Trapero, F. G. A., Parra, J. C. V. Bosquet, F. J. S. 2018. A Model for a Biotechnological Enterprise Based on Sustainability and the Circular Economy: An Approach Based on Mexican Innovations. International Journal of Entrepreneurship, Vol. 22(3). Available at https://www.abacademies.org/articles/a-model-for-a-biotechnological-enterprise-based-on-sustainability-and-thecircular-economy-an-approach-based-on-mexican-innovation-7425.html

22. United Nations. 2015. Transforming our world: the 2030 Agenda for Sustainable Development. Resolution adopted by the General Assembly on 25 September 2015. Available at https://www.un.org/ga/search/view_doc.asp?symbol=A/RES/70/1\&Lang=E

23. Vilmantas, V., Melnikas, B. 2014. Rinkodaros tobulinimas plètojant biotechnologijomis grindžiamą verslą. Verslas: teorija ir praktika, Vol. 15(3), pp. 210-219. https://doi.org/10.3846/btp.2014.21 (In Lithuanian)

24. Wren, S. A. 2012. Socio-economic and livelihood impacts of environmentally supportive bio-enterprise development for the agro/pastoral communities in Samburu Heartland, Kenya. University of Plymouth Research Theses. Available at https://pearl.plymouth.ac.uk/bitstream/handle/10026.1/1093/2012Wren927948phd2.pdf?sequence=2\&isAllowed=y

25. Žitkus, L. 2002. Europietiškojo vadybos modelio bruožai ir integracinių procesų ịtaka jų formavimuisi. Socialiniai mokslai, No. 1(33), pp. 77-84. (In Lithuanian) 